\title{
Influence of the Biofield Energy Therapy on the Physico- chemical and Thermal Properties of Sulfamethoxazole
}

\author{
Dahryn Trivedi ${ }^{1}$, Mahendra Kumar Trivedi ${ }^{1}$, Alice Branton ${ }^{1}$, Gopal Nayak ${ }^{1}$, Snehasis \\ Jana $^{2^{*}}$
}

${ }^{1}$ Trivedi Global, Inc., Henderson, USA

${ }^{2}$ Trivedi Science Research Laboratory Pvt. Ltd., Bhopal, India

*Corresponding author: Snehasis Jana, Trivedi Science Research Laboratory Pvt. Ltd., Bhopal, India. Tel: +91-022-25811234; Email: publication@trivedieffect.com

\begin{abstract}
Sulfamethoxazole is an antibiotic, which inhibits the bacteria by interfering in its folic acid synthesis mechanism. The objective of this study was to analyze the Trivedi Effect ${ }^{\mathbb{R}}$-Consciousness Energy Healing Treatment on the physicochemical and thermal properties of sulfamethoxazole by using modern analytical techniques. The sulfamethoxazole sample was classified as control and treated samples. The control sample did not receive the Biofield Treatment, while the treated sample received the Biofield Treatment remotely by a renowned Biofield Energy Healer, Dahryn Trivedi. The particle sizes of the treated sample were significantly reduced by $7.99 \%\left(\mathrm{~d}_{10}\right), 3.05 \%\left(\mathrm{~d}_{50}\right), 3.80 \%\left(\mathrm{~d}_{90}\right)$, and $3.03 \%\{\mathrm{D}(4,3)\}$; whereas, the specific surface area of the particles was increased by $5.19 \%$ in the treated sample compared to the control sample. The PXRD peak intensities and crystallite sizes were altered ranging from $-70.86 \%$ to $52.36 \%$ and $-6.01 \%$ to $75.34 \%$, respectively; whereas the average crystallite size was significantly increased by $27.28 \%$ in the treated sulfamethoxazole compared with the control sample. The sample residual amount and maximum thermal degradation temperature were increased by $2.13 \%$ and $4.21 \%$, respectively, in the treated sample compared to the control sample. The decomposition temperature and latent heat of decomposition were increased by $3.26 \%$ and $19.36 \%$, respectively, in the treated sample compared to the untreated sample. The Biofield Treated sulfamethoxazole might convert to a novel polymorph of the drug, with reduced particle size, increased surface area, and improved thermal stability. This can be helpful in improving the solubility, bioavailability, and stability of the sulfamethoxazole and would be more efficacious for the treatment of infections in the ear, urinary tract infections, traveler's diarrhoea, bronchitis, shigellosis, and pneumonia, etc.
\end{abstract}

Keywords: Sulfamethoxazole, Consciousness Energy Healing Treatment, The Trivedi Effect ${ }^{\circledR}$, Complementary and Alternative Medicine, Particle size, PXRD, TGA/DTG

\section{Introduction}

Sulfamethoxazole is a broad spectrum antibiotic, which is effective against both the Gram positive and Gram negative bacteria such as Listeria monocytogenes and E. coli and is used to treat the bacterial infections such as bronchitis, urinary tract infections, and prostatitis etc ${ }^{[1]}$. It is bacteriostatic in nature and acts by preventing the folic acid synthesis in some bacteria ${ }^{[2,3]}$. The combination of sulfamethoxazole and trimethoprim is used to treat various microbial infections such as bronchitis, urinary tract infections, traveller's diarrhoea, middle ear infections (otitis media), and bacillary dysentery (shigellosis) ${ }^{[4]}$. Apart from that, this combination is also used in the treatment of infections caused by streptococci, Toxoplasma gondii, Pneumocystis jiroveci, Nocardia, Salmonella, methicillin-resistant Staphylococcus aureus ${ }^{[5]}$, Mycobacterium tuberculosis ${ }^{[6]}$, Stenotrophomonas maltophila ${ }^{[7]}$, etc.

Although, sulfamethoxazole is well absorbed orally; however, the bioavailability of any drug is affected by its stability and analytical profile ${ }^{[8]}$. The physicochemical properties of pharmaceutical compounds play a vital role in its solubility, dissolution, stability, and bioavailability profile. Hence, several techniques are used by researchers in order to improve the biological activities of drug molecules through altering its physiochemical
Received date: September 19, 2018 Accepted date: October 29, 2018 Published date: November 5, 2018

Citation: Dahryn Trivedi., et al. Influence of the Biofield Energy Therapy on the Physicochemical and Thermal Properties of Sulfamethoxazole. (2018) J Med Chem Toxicol 3(1): 19-25.

Copy Rights: (C) 2018 Dahryn Trivedi. This is an Open access article distributed under the terms of Creative Commons Attribution 4.0 International License. 
Citation: Dahryn Trivedi., et al. Influence of the Biofield Energy Therapy on the Physicochemical and Thermal Properties of Sulfamethoxazole. (2018) J Med Chem Toxicol 3(1): 19- 25 .

properties such as such as crystalline structure, particle size, surface area, thermal stability, etc ${ }^{[9,10]}$.

The Consciousness Energy Healing Treatment has been reported in various scientific studies due to its ability to alter the physical, structural, and thermal properties of the pharmaceutical and nutraceutical compounds ${ }^{[11,12]}$. Energy therapies are also used in the integrated healthcare approach along with the Complementary and Alternative Medicine (CAM) therapies for the treatment of various health conditions ${ }^{[13,14]}$. Various alternative healing therapies such as yoga, meditation, homeopathy, acupressure, acupuncture, hypnotherapy, healing touch, relaxation techniques, Pilates, Reiki, Ayurvedic medicine, traditional Chinese herbs and medicines, cranial sacral therapy, etc. are recommended by the National Institutes of Health $(\mathrm{NIH})$ to include under the CAM category and such therapies are also accepted by huge population due to their advantages ${ }^{[15,16]}$. In a similar way, the Biofield Energy Healing (the Trivedi Effect ${ }^{\circledR}$ ) also become popular worldwide because of its significant impact on the non-living materials as well as the living organisms. The Trivedi Effect $^{\mathbb{}}$-Consciousness Energy Healing Treatment has been reported for its significant impact on the properties of crops ${ }^{[17]}$, metals, ceramics, and polymers ${ }^{[18]}$, altered characteristics in microbes $^{[19]}$, plants ${ }^{[20]}$, livestock ${ }^{[21]}$, and skin health ${ }^{[22]}$. Thus, this study was aimed to determine the effect of the Biofield Energy Treatment (the Trivedi Effect ${ }^{\circledR}$ ) on the physicochemical and thermal properties of sulfamethoxazole by using various analytical techniques such as, particle size analysis (PSA), powder X-ray diffraction (PXRD), Thermogravimetric analysis (TGA), and differential scanning calorimetry (DSC).

\section{Materials and Methods}

\section{Chemicals and Reagents}

The sulfamethoxazole sample was purchased from Sigma Aldrich, USA. All other chemicals used during the experiments were of analytical grade available in India.

\section{Consciousness Energy Healing Treatment Strategies}

The sulfamethoxazole sample was divided into two equal parts. One part of sulfamethoxazole did not receive the Biofield Energy Treatment and the sample was considered as a control sample. Further, the control sample was treated with a "sham" healer for comparison purpose. The "sham" healer did not have any knowledge about the Biofield Energy Treatment. However, the second part of sulfamethoxazole was treated with the Biofield Energy Treatment remotely under standard laboratory conditions for 3 minutes and known as a treated sample. This Biofield Energy Treatment was provided through the healer's unique energy transmission process by the renowned Biofield Energy Healer, Dahryn Trivedi, USA, to one part of the test sample. After the treatment both the samples were kept in the sealed conditions and characterized using PSA, PXRD, TGA/ DTG, and DSC analytical techniques.

\section{Characterization \\ Particle Size Analysis (PSA)}

The particle size analysis of sulfamethoxazole samples was conducted on Malvern Mastersizer 2000, of the UK with a detection range between $0.01 \mu \mathrm{m}$ to $3000 \mu \mathrm{m}$ using wet method $^{[23,24]}$. The sample unit (Hydro MV) was filled with a dis- persant medium (sunflower oil) and the stirrer operated at 2500 $\mathrm{rpm}$. The PSA analysis of sulfamethoxazole was performed to obtain the average particle size distribution. Where, $\mathrm{d}(0.1) \mu \mathrm{m}$, $\mathrm{d}(0.5) \mu \mathrm{m}, \mathrm{d}(0.9) \mu \mathrm{m}$ represent particle diameter corresponding to $10 \%, 50 \%$, and $90 \%$ of the cumulative distribution. $\mathrm{D}(4,3)$ represents the average mass-volume diameter, and SSA is the specific surface area $\left(\mathrm{m}^{2} / \mathrm{g}\right)$. The calculations were done by using software Mastersizer Ver. 5.54.

The percent change in particle size (d) at below $10 \%$ level $\left(\mathrm{d}_{10}\right), 50 \%$ level $\left(\mathrm{d}_{50}\right), 90 \%$ level $\left(\mathrm{d}_{90}\right)$, and $\mathrm{D}(4,3)$ was calculated using the following equation 1 :

$\%$ change in particle size $=\frac{\left[\mathrm{d}_{\text {Treated }}-\mathrm{d}_{\text {Control }}\right]}{\mathrm{d}_{\text {Control }}} \times 100$

Where $\mathrm{d}_{\text {Control }}$ and $\mathrm{d}_{\text {Treated }}$ are the particle size $(\mu \mathrm{m})$ for at below $10 \%$ level $\left(\mathrm{d}_{10}\right), 50 \%$ level $\left(\mathrm{d}_{50}\right)$, and $90 \%$ level $\left(\mathrm{d}_{90}\right)$ of the control and the Biofield Energy Treated sulfamethoxazole samples, respectively.

The percent change in surface area (S) was calculated using the following equation 2 :

$\%$ change in surface area $=\frac{\left[\mathrm{S}_{\text {Treated }}-\mathrm{S}_{\text {Control }}\right]}{\mathrm{S}_{\text {Control }}} \times 100$

Where $\mathrm{S}_{\text {Control }}$ and $\mathrm{S}_{\text {Treated }}$ are the surface area of the control and the Biofield Energy Treated sulfamethoxazole samples, respectively.

\section{Powder X-ray Diffraction (PXRD) Analysis}

The PXRD analysis of control and the Biofield Energy Treated sulfamethoxazole was performed with the help of Rigaku MiniFlex-II Desktop X-ray diffractometer (Japan) ${ }^{[25,26]}$. The $\mathrm{Cu} \mathrm{K \alpha}$ radiation source tube output voltage used was $30 \mathrm{kV}$ and tube output current were $15 \mathrm{~mA}$. Scans were performed at room temperature. The average size of individual crystallites was calculated from XRD data using the Scherrer's formula (3):

$\mathrm{G}=\mathrm{k} \lambda / \beta \cos \theta$

Where $\mathrm{k}$ is the equipment constant (0.94), $\mathrm{G}$ is the crystallite size in $\mathrm{nm}, \lambda$ is the radiation wavelength $(0.154056 \mathrm{~nm}$ for $\mathrm{K} \alpha 1$ emission), $\beta$ is the full-width at half maximum (FWHM), and $\theta$ is the Bragg angle $\mathrm{e}^{[27]}$.

The \% change in crystallite size (G) of sulfamethoxazole was calculated using the following equation 4 :

$\%$ change in crystallite size $=\frac{\left[G_{\text {Treated }}-G_{\text {Control }}\right]}{G_{\text {Control }}} \times 100$ (4)

Where $G_{\text {Control }}$ and $G_{\text {Treated }}$ are the crystallite size of the control and the Biofield Energy Treated samples, respectively.

\section{Thermal Gravimetric Analysis (TGA)/ Differential Thermo- gravimetric analysis (DTG)}

TGA/DTG thermograms of the control and the Biofield Energy Treated sulfamethoxazole were obtained with the help of TGA Q50TA instruments. A sample of $4-15 \mathrm{mg}$ was loaded to the platinum crucible at a heating rate of $10^{\circ} \mathrm{C} / \mathrm{min}$ from $25^{\circ} \mathrm{C}$ to $1000^{\circ} \mathrm{C}$ with the recent literature ${ }^{[23,24]}$. The $\%$ change in weight loss $(\mathrm{W})$ was calculated using the following equation 5 : 
$\%$ change in weight loss $=\frac{\left[w_{\text {Treated }}-w_{\text {Control }}\right]}{w_{\text {Control }}} \times 100$

Where $\mathrm{W}_{\text {Control }}$ and $\mathrm{W}_{\text {Treated }}$ are the weight loss of the control and the Biofield Energy Treated sulfamethoxazole, respectively.

The $\%$ change in maximum thermal degradation temperature $\left(\mathrm{T}_{\max }\right)(\mathrm{M})$ was calculated using the following equation 6:

$$
\% \text { change in } \operatorname{Tmax}(M)=\frac{\left[\mathrm{M}_{\text {Treated }}-\mathrm{M}_{\text {Control }}\right]}{\mathrm{M}_{\text {Control }}} \times 100
$$

Where $\mathrm{M}_{\text {Control }}$ and $\mathrm{M}_{\text {Treated }}$ are the $\mathrm{T}_{\max }$ values of the control and the Biofield Energy Treated sulfamethoxazole, respectively.

\section{Differential Scanning Calorimetry (DSC)}

The DSC analysis of sulfamethoxazole was performed with the help of DSC Q200, TA instruments. A sample of $\sim 1-5$ $\mathrm{mg}$ was loaded into the aluminium sample pan at a heating rate of $10^{\circ} \mathrm{C} / \mathrm{min}$ from $30^{\circ} \mathrm{C}$ to $350^{\circ} \mathrm{C}^{[23,24]}$. The percent change in melting point $(\mathrm{T})$ was calculated using the following equation 7 :

$$
\% \text { change in melting point }=\frac{\left[\mathrm{T}_{\mathrm{Tr} \text { eated }}-\mathrm{T}_{\text {Control }}\right]}{\mathrm{T}_{\text {Control }}} \times 100
$$

Where $\mathrm{T}_{\text {Control }}$ and $\mathrm{T}_{\text {Treated }}$ are the melting point of the control and the treated samples, respectively.

The $\%$ change in the latent heat of fusion $(\Delta \mathrm{H})$ was calculated using the following equation 8 :

$\%$ change in the latent heat of fusion $=\frac{\left[\Delta \mathrm{H}_{\text {Treated }}-\Delta \mathrm{H}_{\text {Control }}\right]}{\Delta \mathrm{H}_{\text {Control }}} \times 100$

Where $\Delta \mathrm{H}_{\text {Control }}$ and $\Delta \mathrm{H}_{\text {Treated }}$ are the latent heat of fusion of the control and the treated sulfamethoxazole, respectively.

\section{Results and Discussion}

\section{Particle Size Analysis (PSA)}

The particle size analysis corresponding to $10 \%, 50 \%$, and $90 \%$ of the cumulative distribution and average mass-volume diameter of the control and the Biofield Energy Treated sulfamethoxazole samples were done and the results are given in Table 1. The particle size distribution of the control sulfamethoxazole sample at $\mathrm{d}_{10}, \mathrm{~d}_{50}, \mathrm{~d}_{90}$, and $\mathrm{D}(4,3)$ was observed as $14.76 \mu \mathrm{m}, 45.85 \mu \mathrm{m}, 102.39 \mu \mathrm{m}$, and $53.23 \mu \mathrm{m}$, respectively. However, the particle size distribution of the Biofield Energy Treated sample was found to be decreased by $7.99 \%, 3.05 \%$, $3.80 \%$, and $3.93 \%$ at $\mathrm{d}_{10}, \mathrm{~d}_{50}, \mathrm{~d}_{90}$, and $\mathrm{D}(4,3)$, respectively, compared to the control sample (Table 1).

The specific surface area of the Biofield Energy Treated sulfamethoxazole was observed as $0.324 \mathrm{~m}^{2} / \mathrm{g}$, which was increased by $5.19 \%$ as compared to the SSA of the control sample $\left(0.308 \mathrm{~m}^{2} / \mathrm{g}\right)$. The resultant increase in the surface area of the treated sample might occur due to the significant reduction in the particle size as compared to the control sample. It is presumed here that the Trivedi Effect ${ }^{\circledR}$ might behave as an external force that reduces the particle sizes of the sulfamethoxazole sample. The particle size distribution of drug has a significant impact on the solubility, absorption, bioavailability, and complete drug performance in the body ${ }^{[28,29]}$. Also, the reduction in particle size increases the surface area of the compound, which is used as a technique to enhance the solubility and bioavailability of the drug $^{[30]}$. Hence, the particle size analysis of the treated sulfamethoxazole indicated the possible improvement in its bioavailability profile after the Biofield Energy Treatment as compared to the untreated sample.

Table 1: Particle size distribution of the control and the Biofield Energy Treated sulfamethoxazole.

\begin{tabular}{|l|c|c|c|c|c|}
\hline Parameter & $\mathbf{d}_{\mathbf{1 0}}(\boldsymbol{\mu m})$ & $\mathbf{d}_{\mathbf{5 0}}(\boldsymbol{\mu m})$ & $\mathbf{d}_{\mathbf{9 0}}(\boldsymbol{\mu m})$ & $\begin{array}{c}\mathbf{D}(\mathbf{4 , 3}) \\
(\boldsymbol{\mu m})\end{array}$ & $\begin{array}{c}\text { SSA } \\
\left(\mathbf{m}^{2} / \mathbf{g}\right)\end{array}$ \\
\hline Control & 14.76 & 45.85 & 102.39 & 53.23 & 0.308 \\
\hline $\begin{array}{l}\text { Biofield } \\
\text { Treated }\end{array}$ & 13.58 & 44.45 & 98.50 & 51.14 & 0.324 \\
\hline $\begin{array}{l}\text { Percent } \\
\text { change*(\%) }\end{array}$ & -7.99 & -3.05 & -3.80 & -3.93 & 5.19 \\
\hline
\end{tabular}

$\mathrm{d}_{10}, \mathrm{~d}_{50}$, and $\mathrm{d}_{90}$ : particle diameter corresponding to $10 \%, 50 \%$, and $90 \%$ of the cumulative distribution, $\mathrm{D}(4,3)$ : the average mass-volume diameter, and SSA: the specific surface area. *denotes the percentage change in the Particle size distribution of the Biofield Energy Treated sample with respect to the control sample.

\section{Powder X-ray Diffraction (PXRD) Analysis}

The PXRD diffractograms of the control and Biofield Energy Treated sulfamethoxazole samples are shown in Figure 1. The presence of sharp and intense peaks in the diffractograms of both the samples revealed their crystalline nature. The data regarding the Bragg's angle, relative intensities, and crystallite sizes for both the samples are given in Table 2 along with their further analysis.

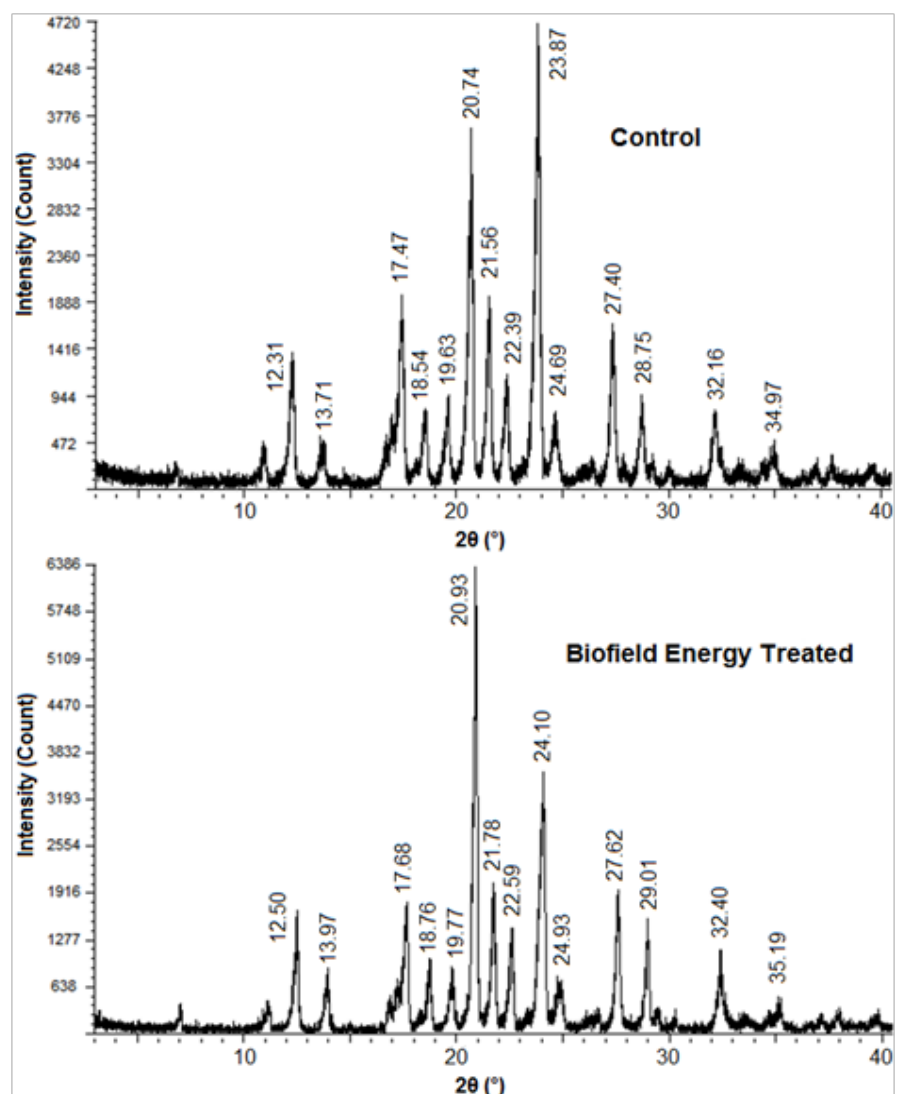

Figure 1: PXRD diffractograms of the control and Biofield Energy Treated sulfamethoxazole. 
Citation: Dahryn Trivedi., et al. Influence of the Biofield Energy Therapy on the Physicochemical and Thermal Properties of Sulfamethoxazole. (2018) J Med Chem Toxicol 3(1): 19- 25.

The data showed that the highest peak intensity $(100 \%)$ in the diffractogram of the control sample was observed at $2 \theta$ equal to $23.87^{\circ}$, while it was observed at $2 \theta$ equal to $20.93^{\circ}$ in the Biofield Energy Treated sample. The significant alterations were also found in the Bragg's angle of the other characteristic peaks of the Biofield Energy Treated sample as compared to the control sulfamethoxazole sample. The peak intensities of the characteristic peaks of the Biofield Energy Treated sample were observed to be altered ranging from $-70.86 \%$ to $52.36 \%$, as compared to the control sample, which might indicate the possible changes in the crystallinity of the treated sulfamethox- azole sample in comparison to the untreated one. Similarly, the crystallite sizes corresponding to most of the characteristic diffraction peaks of the Biofield Energy Treated sample were significantly altered ranging from $-6.01 \%$ to $75.34 \%$ as compared to the control sample. Also, the alterations were observed in the average crystallite size of the Biofield Energy Treated sample $(375.57 \mathrm{~nm})$, which was significantly increased by $27.28 \%$ as compared to the control sample $(295.07 \mathrm{~nm})$. Hence, the overall PXRD data indicated the alterations in the crystallinity and the crystallite size of the treated sulfamethoxazole sample after the Biofield Energy Treatment, as compared to the control sample.

Table 2: PXRD data for the control and Biofield Energy Treated sulfamethoxazole.

\begin{tabular}{|c|c|c|c|c|c|c|c|c|}
\hline \multirow{2}{*}{ Entry No. } & \multicolumn{2}{|c|}{ Bragg angle $\left({ }^{\circ} 2 \theta\right)$} & \multicolumn{2}{|c|}{ Intensity (cps) } & \multicolumn{4}{|c|}{ Crystallite size (G, nm) } \\
\hline & Control & Treated & Control & Treated & $\%$ Change $^{\mathrm{a}}$ & Control & Treated & \% Change ${ }^{b}$ \\
\hline 1 & 12.31 & 12.50 & 249 & 276 & 10.84 & 296 & 519 & 75.34 \\
\hline 2 & 13.71 & 13.97 & 82 & 119 & 45.12 & 270 & 338 & 25.19 \\
\hline 3 & 17.47 & 17.68 & 352 & 263 & -25.28 & 273 & 336 & 23.08 \\
\hline 4 & 18.54 & 18.76 & 122 & 171 & 40.16 & 332 & 419 & 26.20 \\
\hline 5 & 19.63 & 19.77 & 128 & 130 & 1.56 & 339 & 539 & 59.00 \\
\hline 6 & 20.74 & 20.93 & 615 & 937 & 52.36 & 313 & 405 & 29.39 \\
\hline 7 & 21.56 & 21.78 & 332 & 318 & -4.22 & 353 & 416 & 17.85 \\
\hline 8 & 22.39 & 22.59 & 162 & 222 & 37.04 & 320 & 393 & 22.81 \\
\hline 9 & 23.87 & 24.10 & 927 & 715 & -22.87 & 283 & 266 & -6.01 \\
\hline 10 & 24.69 & 24.93 & 146 & 133 & -8.90 & 240 & 243 & 1.25 \\
\hline 11 & 27.40 & 27.62 & 284 & 304 & 7.04 & 322 & 378 & 17.39 \\
\hline 12 & 28.75 & 29.01 & 439 & 192 & -56.26 & 313 & 396 & 26.52 \\
\hline 13 & 32.16 & 32.40 & 381 & 210 & -44.88 & 235 & 298 & 26.81 \\
\hline 14 & 34.97 & 35.19 & 175 & 51 & -70.86 & 242 & 312 & 28.93 \\
\hline
\end{tabular}

*denotes the percentage change in the crystallite size of Biofield Energy Treated sample with respect to the control sample.

Some studies reported that the Biofield Energy Treatment might produce a new polymorph of the compound by changing the peak intensities and crystallite sizes and thereby affecting the morphology and crystalline structure of the compound ${ }^{[31,32]}$. Thus, the significant changes taking place in the peak intensities and crystallite size of the treated sample might be resulted due to the formation of a new polymorph of the sulfamethoxazole sample after the Biofield Energy Treatment, which might improve the drug profile of sulfamethoxazole compared to the untreated sample.

\section{Thermal Gravimetric Analysis (TGA)/ Differential Thermo- gravimetric Analysis (DTG)}

The TGA/DTG technique was used to analyse the impact of the Biofield Energy Treatment on the thermal stability profile of the treated sulfamethoxazole sample in comparison to the untreated sample. The TGA data for both the samples (Figure 2) revealed that there was a slight reduction (1.04\%) in the total weight loss of the Biofield Energy Treated sample during the sample degradation as compared to the control sample. Hence, the residue amount of the Biofield Energy Treated sulfamethoxazole sample was increased by $2.13 \%$ (Table 3 ) in comparison to the control sample. Thus, it indicated the improved thermal stability of the treated sulfamethoxazole sample after the Biofield Energy Treatment, as compared to the untreated sample.
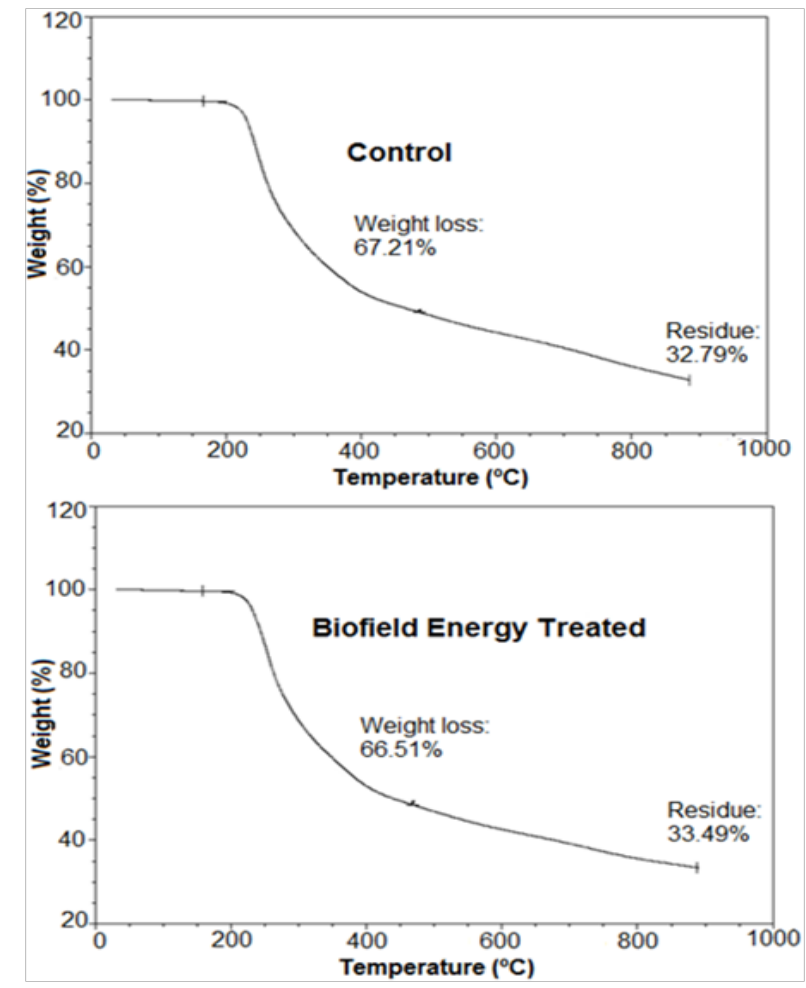

Figure 2: TGA thermograms of the control and Biofield Energy Treated sulfamethoxazole. 
Table 3: TGA/DTG data of the control and Biofield Energy Treated samples of sulfamethoxazole.

\begin{tabular}{|l|c|c|c|}
\hline \multirow{2}{*}{ Sample } & \multicolumn{2}{|c|}{ TGA } & DTG \\
\cline { 2 - 4 } & $\begin{array}{c}\text { Total weight } \\
\text { loss (\%) }\end{array}$ & Residue \% & T $_{\text {max }}\left({ }^{\circ} \mathbf{C}\right)$ \\
\hline Control & 67.21 & 32.79 & 242.83 \\
\hline $\begin{array}{l}\text { Biofield Energy } \\
\text { Treated }\end{array}$ & 66.51 & 33.49 & 253.06 \\
\hline \% Change* & -1.04 & 2.13 & 4.21 \\
\hline
\end{tabular}

*denotes the percentage change of the Biofield Energy Treated sample with respect to the control sample,

$\mathrm{T}_{\max }=$ the temperature at which maximum weight loss takes place in TG or peak temperature in DTG.
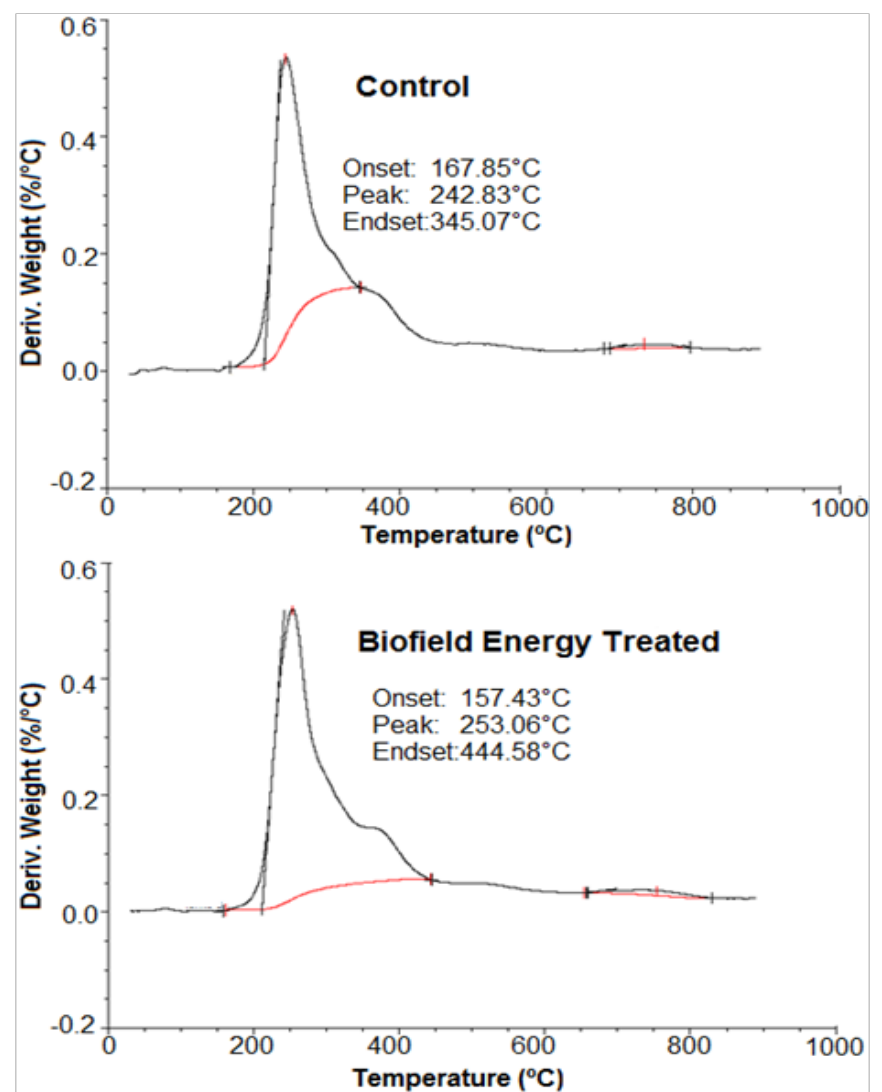

Figure 3: DTG thermograms of the control and Biofield Energy Treated sulfamethoxazole.

The DTG thermograms (Figure 3) of both the samples showed single peak, and their results revealed the significant improvement $(4.21 \%)$ in the maximum degradation temperature $\left(\mathrm{T}_{\max }\right)$ of the Biofield Energy Treated sample $\left(253.06^{\circ} \mathrm{C}\right)$, as compared to the $\mathrm{T}_{\text {max }}$ of the control sample $\left(242.83^{\circ} \mathrm{C}\right)$. Overall, the TGA/DTG studies showed that the thermal stability of the Biofield Energy Treated sample was improved, which might occur due to the possible alteration in the crystalline structure of the treated sulfamethoxazole, as compared with the untreated sample.

\section{Differential Scanning Calorimetry (DSC) Analysis}

DSC analysis is used as a technique for determining the thermodynamic changes that will occur during the heating of drug. Such changes might involve melting, recrystallization, and de-solvation, etc. that represent themselves in the form of the endothermic or exothermic peaks on the DSC thermograms ${ }^{[33]}$.
The studies reported the presence of two peaks in the DSC curve of sulfamethoxazole. The first peak reported was an endothermic peak that is present $\sim 172{ }^{\circ} \mathrm{C}$ and denotes the fusion process; while the second peak was exothermic in nature (exist $\sim 270{ }^{\circ} \mathrm{C}$ ) and showed the oxidation of evolved products as a result of the thermal decomposition of the sample ${ }^{[34]}$. The DSC thermograms of both the samples (Figure 4) were observed similarly as reported in the literature. The first endothermic peak, i.e., the melting/ fusion peak was observed at a similar temperature in the thermograms of both the samples. The results showed a slight increase $(0.28 \%)$ in the melting point and slight reduction in the latent heat of fusion $\left(\Delta \mathrm{H}_{\text {fusion }}\right)(0.38 \%)$ of the Biofield Energy Treated sample, compared to the control sulfamethoxazole sample (Table 4).
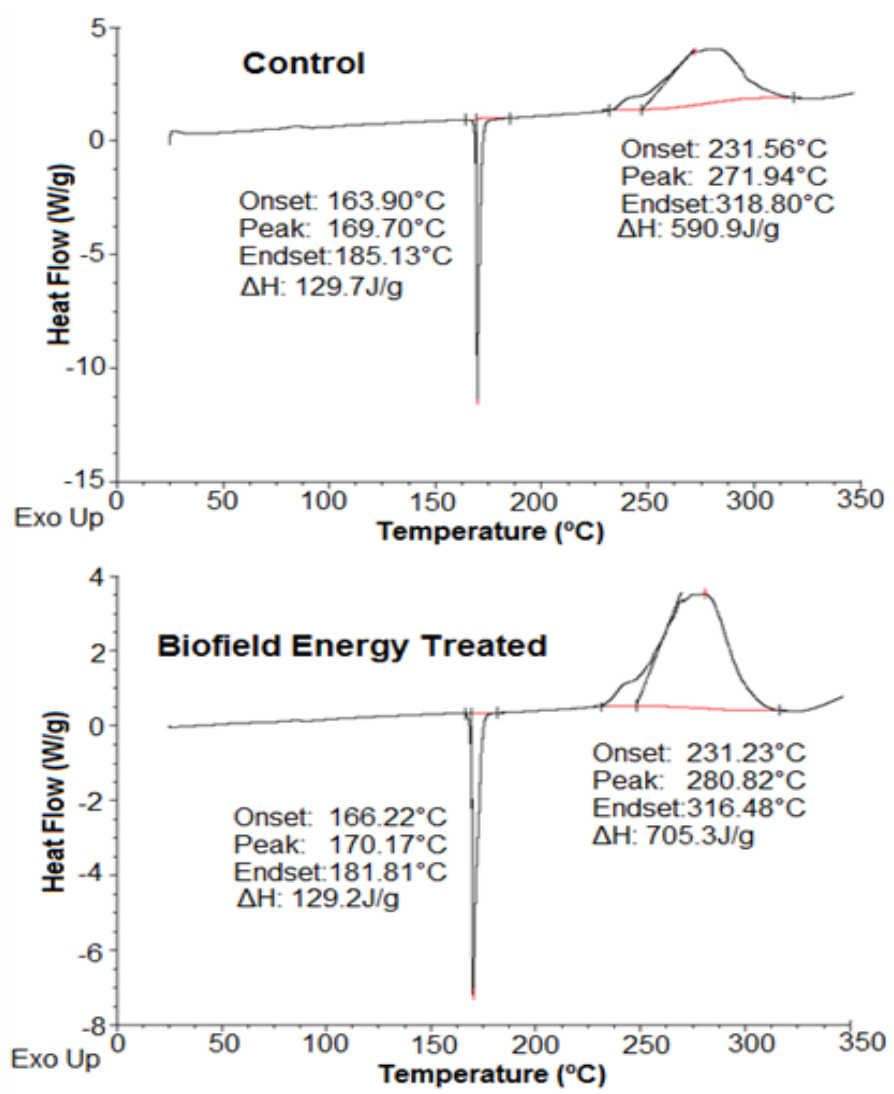

Figure 4: DSC thermograms of the control and Biofield Energy Treated sulfamethoxazole.

Table 4: Comparison of DSC data between the control and Biofield Energy Treated sulfamethoxazole.

\begin{tabular}{|l|l|c|c|}
\hline Peak & Description & Melting Point $\left({ }^{\circ} \mathbf{C}\right)$ & $\Delta \mathbf{H}_{\text {fusion }}(\mathbf{J} / \mathbf{g})$ \\
\hline \multirow{4}{*}{ Peak 1 } & Control sample & 169.70 & 129.70 \\
\cline { 2 - 4 } & $\begin{array}{l}\text { Biofield Treated } \\
\text { sample }\end{array}$ & 170.17 & 129.20 \\
\cline { 2 - 4 } & \% Change* & 0.28 & -0.38 \\
\hline \multirow{3}{*}{ Peak 2 } & Control sample & 271.94 & 590.90 \\
\cline { 2 - 4 } & $\begin{array}{l}\text { Biofield Treated } \\
\text { sample }\end{array}$ & 280.82 & 705.30 \\
\cline { 2 - 4 } & \% Change* & 3.26 & 19.36 \\
\hline
\end{tabular}

$\Delta \mathrm{H}$ : Latent heat of fusion; *denotes the percentage change of the Biofield Energy Treated sample with respect to the control sample. 
Citation: Dahryn Trivedi., et al. Influence of the Biofield Energy Therapy on the Physicochemical and Thermal Properties of Sulfamethoxazole. (2018) J Med Chem Toxicol 3(1): 19- 25.

The thermograms of the control and the treated sample also possess a broad exothermic inflection, which is resulted due to oxidation of evolved products and thermal decomposition of the samples. The results showed that the temperature corresponding to this peak of the Biofield Energy Treated sample was increased by $3.26 \%$ along with $19.36 \%$ increase in the $\Delta H$, as compared to the control sample. Thus, the DSC data indicated the improved thermal stability of the treated sulfamethoxazole sample after the Biofield energy Treatment as compared to the untreated sample. It is presumed that the Biofield Energy treatment might cause some alterations in the molecular chains and crystallization structure of the sulfamethoxazole sample, which might be responsible for the improved thermal stability profile of the treated sulfamethoxazole sample ${ }^{[35]}$.

\section{Conclusion}

The Trivedi Effect ${ }^{\circledR}$-Consciousness Energy Healing Treatment has shown a significant impact on the physicochemical and thermal properties of sulfamethoxazole drug. The Biofield Energy Treated sample showed a significant reduction in the particle size by $7.99,3.05 \%, 3.80 \%$, and $3.93 \%$ at $\mathrm{d}_{10}, \mathrm{~d}_{50}$, $\mathrm{d}_{90}$, and $\mathrm{D}(4,3)$, respectively, compared to the untreated sample. Thus, the specific surface area of the Biofield Energy Treated sulfamethoxazole was increased by $5.19 \%$ compared with the control sample. Such changes might increase the solubility, dissolution, and absorption parameters and thereby increase the bioavailability of the treated sulfamethoxazole as compared to the untreated sample. The PXRD peak intensities and the crystallite sizes of the Biofield Energy Treated sample were significantly altered ranging from $-70.86 \%$ to $52.36 \%$ and $-6.01 \%$ to $75.34 \%$, respectively, compared to the untreated sample. The average crystallite size of the Biofield Energy Treated sample was significantly increased by $27.28 \%$ as compared to the control sample. The Biofield Energy Treated sample also showed a $4.21 \%$ significant increase in the $T_{\max }$ as compared with the control sample. The decomposition temperature and $\Delta \mathrm{H}_{\text {decom- }}$ of the Biofield Energy Treated sample were significantly increased by $3.26 \%$ and $19.36 \%$, respectively, as compared to the control sample. Thus, the thermal studies of the Biofield Energy Treated sulfamethoxazole indicated its improved thermal stability in comparison to the untreated sample. The overall study concluded that the Trivedi Effect ${ }^{\mathbb{R}}$-Consciousness Energy Healing Treatment might create a new polymorphic form of the drug with altered crystallinity that might possess better solubility, dissolution, bioavailability, and improved thermal stability as compared with the untreated sample. Hence, the Biofield Energy Treated sulfamethoxazole may have better efficacy for the prevention and treatment of various bacterial diseases such as ear infections, urinary tract infections, traveler's diarrhea, bronchitis, shigellosis, and Pneumocystis jiroveci pneumonia, etc.

\section{Acknowledgements}

The authors are grateful to Central Leather Research Institute, SIPRA Lab. Ltd., Trivedi Science, Trivedi Global, Inc., Trivedi Testimonials, and Trivedi Master Wellness for their assistance and support during this work.

\section{References}

1. Neu, H.C., Gootz, T.D. Antimicrobial Chemotherapy. (1996) Medical Microbiology. 4th ed.

Pubmed | Crossref $\mid$ Others

2. Zander, J., Besier, S., Ackermann, H., et al. Synergistic antimicrobial activities of folic acid antagonists and nucleoside analogs. (2010) Antimicrob Agents Chemother 54(3): 1226-1231.

Pubmed |Crossref $\mid$ Others

3. Schwalbe, R., Steele-Moore, L., Goodwin, A.C. Antimicrobial Susceptibility Testing Protocols.(2007).

Pubmed | Crossref $\mid$ Others

4. Brunton, L., Chabner, B.A., Knollman, B. Goodman and Gilman's the pharmacological Basis of Therapeautics.(2011) The McGraw-Hill Companies Inc.

Pubmed | Crossref | Others

5. Ho, J.M., Juurlink, D.N. Considerations when prescribing trimethoprim-sulfamethoxazole. (2011) CMAJ 183(16): 1851-1858.

Pubmed | Crossref| Others

6. Vilcheze, C., Jacobs, W.R. The combination of sulfamethoxazole, trimethoprim, and isoniazid or rifampin is bactericidal and prevents the emergence of drug resistance in mycobacterium tuberculosis. (2012) Antimicrob Agents Chemother 56(10): 5142-5148.

Pubmed | Crossref | Others

7. Christaki, E. Folate Inhibitors. Infectious Diseases.4thed. (2017) Elsevier Ltd.

Pubmed | Crossref | Others

8. Mulla, S.I., Hu, A., Sun, Q., et al. Biodegradation of sulfamethoxazole in bacteria from three different origins. (2018) J Environ Manage 206: 93-102.

Pubmed | Crossref | Others

9. Khadka, P., Ro, J., Kim, H., et al. Pharmaceutical particle technologies: An approach to improve drug solubility, dissolution and bioavailability. (2014) Asian J Pharm 9(6): 304-316.

Pubmed | Crossref $\mid$ Others

10. Savjani, K.T., Gajjar, A.K., Savjani, J.K. Drug Solubility: Importance and enhancement techniques. (2012) ISRN Pharm 195727.

Pubmed | Crossref | Others

11. Trivedi, M.K., Patil, S., Shettigar, H., et al. Spectroscopic characterization of biofield treated metronidazole and tinidazole. (2015) Med Chem 5: 340-344.

Pubmed | Crossref $\mid$ Others

12. Trivedi, M.K., Branton, A., Trivedi, D., et al. Evaluation of the Trivedi Effect ${ }^{\mathbb{B}}$ - Energy of Consciousness Energy Healing Treatment on the physical, spectral, and thermal properties of zinc chloride. (2017) Ame J Life Sci 5(1): 11-20.

Pubmed | Crossref| Others

13. Frass, M., Strassl, R.P., Friehs, H., et al. Use and acceptance of complementary and alternative medicine among the general population and medical personnel: A Systematic Review. (2012) Ochsner J 12(1): 45-56.

Pubmed | Crossref $\mid$ Others

14. Barnes, P.M., Bloom, B., Nahin, R.L. Complementary and alternative medicine use among adults and children: United States, 2007. (2008) Natl Health Stat Report 12: 1-23.

Pubmed | Crossref| Others

15. Rubik, B. The biofield hypothesis: Its biophysical basis and role in medicine. (2002) J Altern Complement Med 8(6): 703-717.

Pubmed | Crossref | Others

16. Koithan, M. Introducing complementary and alternative therapies. (2009) J Nurse Pract 6(1): 18-20.

Pubmed $\mid$ Crossref $\mid$ Others

17. Trivedi, M.K., Branton, A., Trivedi, D., et al. Morphological characterization, quality, yield and DNA fingerprinting of biofield energy treated alphonso mango (Mangifera indica L.). (2015) J Food Nut Sci 3: $245-250$. 
Pubmed $\mid$ Crossref $\mid$ Others

18. Trivedi, M.K., Tallapragada, R.M., Branton, A., et al. Analysis of physical, thermal, and structural properties of biofield energy treated molybdenum dioxide. (2015) Int J Mate Sci Appl 4: 354-359.

Pubmed |Crossref| Others

19. Trivedi, M.K., Patil, S., Shettigar, H., et al. Evaluation of biofield modality on viral load of Hepatitis B and C viruses. (2015) J Antivir Antiretrovir 7(3): 083-088.

Pubmed | Crossref | Others

20. Nayak, G., Altekar, N. Effect of biofield treatment on plant growth and adaptation. (2015) J Environ Health Sci1: 1-9.

Pubmed | Crossref $\mid$ Others

21. Trivedi, M.K., Branton, A., Trivedi, D., et al. Effect of Biofield treated energized water on the growth and health status in chicken ( $\mathrm{Gal}$ lus gallus domesticus). (2015) Poult Fish WildlSci 3(2): 140.

Pubmed | Crossref| Others

22. Kinney, J.P., Trivedi, M.K., Branton, A., et al. Overall skin health potential of the biofield energy healing based herb mineral formulation using various skin parameters. (2017) Amer J Life Sci 5(2): 65-74.

Pubmed |Crossref | Others

23. Trivedi, M.K., Sethi, K.K., Panda, P., et al. A comprehensive physicochemical, thermal, and spectroscopic characterization of zinc (II) chloride using $\mathrm{X}$ ray diffraction, particle size distribution, differential scanning calorimetry, thermogravimetric analysis/differential thermogravimetric analysis, ultraviolet visible, and Fourier transform infrared spectroscopy. (2017) Inte J Pharm Inv 7(1): 33- 40.

Pubmed|Crossref|Others

24. Trivedi, M.K., Sethi, K.K., Panda, P., et al. Physicochemical, thermal and spectroscopic characterization of sodium selenate using XRD, PSD, DSC, TGA/DTG, UV-vis, and FT-IR. (2017) Mar Pharma J 21(2): 311-318.

Pubmed | Crossref $\mid$ Others

25. Desktop X-ray Diffractometer "MiniFlex+". (1997) The Rigaku J

14: 29-36.

Pubmed $\mid$ Crossref $\mid$ Others

26. Zhang, T., Paluch, K., Scalabrino, G., et al. Molecular structure studies of (1S, 2S)-2-benzyl-2, 3-dihydro-2-(1Hinden-2-yl)-1H-inden1-ol. (2015) J MolStruct 1083: 286-299.

Pubmed | Crossref | Others

27. Langford, J.I., Wilson, A.J.C. Scherrer after sixty years: A survey and some new results in the determination of crystallite size. (1978) J

Appl Cryst 11(2): 102-113.

Pubmed | Crossref | Others

28. Loh, Z.H., Samanta, A.K., Heng, P.W.S. Overview of milling techniques for improving the solubility of poorly water-soluble drugs. (2015) Asian J Pharm 10(4): 255-274.

Pubmed |Crossref|Others

29. Khadkaa, P., Ro, J., Kim, H., et al. Pharmaceutical particle technologies: An approach to improve drug solubility, dissolution and bioavailability. (2014) Asian J Pharm 9(6): 304-316.

Pubmed | Crossref | Others

30. Hu, J., Johnston, K.P., Williams, R.O. Nanoparticle engineering processes for enhancing the dissolution rates of poorly water soluble drugs. (2004) Drug Dev Ind Pharm 30(3): 233-245.

Pubmed|Crossref | Others

31. Trivedi, M.K., Branton, A., Trivedi, D., et al. Evaluation of the impact of biofield energy healing treatment (The Trivedi Effect ${ }^{\mathbb{R}}$ ) on the physicochemical, thermal, structural, and behavioral properties of magnesium gluconate. (2017) Int J Nut Food Sci 6(2): 71-82.

Pubmed |Crossref | Others

32. Trivedi, M.K., Branton, A., Trivedi, D., et al. Evaluation of the physicochemical, spectral, thermal and behavioral properties of sodium selenate: influence of the energy of consciousness healing treatment. (2017) American Journal of Quantum Chemistry and Molecular Spectroscopy 2(2): 18-27.

Pubmed | Crossref $\mid$ Others
33. Giron, D. Applications of thermal analysis and coupled techniques in pharmaceutical industry. (2002) J Therm Anal Calorim 68: 335-357. Pubmed | Crossref| Others

34. Fernandes, N.S., Filho, M.A.S.C., Mendes, R., et al. Thermal decomposition of some chemotherapic substances. (1999) J Braz Chem Soc10: 459- 462.

Pubmed | Crossref $\mid$ Others

35. Zhao, Z., Xie, M., Li, Y., et al. Formation of curcumin nanoparticles via solution enhanced dispersion by supercritical $\mathrm{CO}_{2}$. (2015) Int J Nanomedicine 10: 3171-3181.

Pubmed | Crossref | Others

\section{Submit your manuscript to Ommega Publishers and} we will help you at every step:

- We accept pre-submission inquiries

- Our selector tool helps you to find the most relevant journal

- We provide round the clock customer support

- Convenient online submission

- Thorough peer review

- Inclusion in all major indexing services

- Maximum visibility for your research

Submit your manuscript at OMMEgA Publishers https://www.ommegaonline.org/submit-manuscript 